\title{
Studies on the mosquito populations from Coimbatore, Tamil Nadu, India
}

\author{
K. Manimegalai \\ Department of Zoology, Avinashilingam University for Women, Coimbatore, Tamil Nadu 641043, India \\ Email: manijeysu@gmail.com
}

Date of publication (online): 26 June 2010 Date of publication (print): 26 June 2010 ISSN 0974-7907 (online) | 0974-7893 (print)

Editor: R. Ramanibai

Manuscript details:

Ms \# 02304

Received 03 September 2009

Final revised received 26 May 2010

Finally accepted 27 May 2010

Citation: Manimegalai, K. (2010). Studies on the mosquito populations from Coimbatore Tamil Nadu, India. Journal of Threatened Taxa 2(6): 961-969

Copyright: (c) K. Manimegalai 2010. Creative Commons Attribution 3.0 Unported License. JoTT allows unrestricted use of this article in any medium for non-profit purposes, reproduction and distribution by providing adequate credit to the authors and the source of publication.

Author Details: K. MANimegalal is a Reader specializing in mosquito populations, taxonomy based on morphometry and geometry using modern tools like wing shape analysis, PCR studies and other biotechnological studies.

Acknowledgements: I thank Dr. M. Arunachalam for his help in data analysis.

\begin{abstract}
Mosquito prevalence was studied in three areas of Coimbatore City, Tamil Nadu viz., North Coimbatore, Gandhipuram and Kavundampalayam. Culex quinquefasciatus, C. pseudovishnu, C. gelidus and Armigeres subalbatus are prevalent in the study area. Results indicated that $C$. quinquefasciatus was the predominant species in North Coimbatore followed by $C$. pseudovishnu, whereas $A$. subalbatus was the predominant species both in Gandhipuram and Kavundampalayam areas.
\end{abstract}

Keywords: Armigeres subalbatus, Culex pseudovishnu, Culex quinquefasciatus, Coimbatore City, Diptera, Gandhipuram, meterological parameters, population dynamics.

\section{INTRODUCTION}

Diptera represents one of the largest orders of insects with more than 85,000 species including a large number of disease vectors. Prominent among these are mosquitoes, which are placed under the suborder Nematocera and family Culicidae. More than 3100 species of mosquitoes belonging to 34 genera have been recorded under three subfamilies, namely, Anophelinae, Culicinae and Toxorhynchitinae (Knight \& Stone 1977). Among insect pests mosquitoes are considered "Public Enemy Number One" for humans owing to their biting and blood feeding habits and their role as vectors of diseases including filariasis, malaria, yellow fever, dengue fever and Japanese encephalitis (WHO 1996).

The most important disease transmitting and nuisance causing mosquitoes belong to the genera Anopheles, Culex, Aedes, Mansonia, Haemogogus, Sabithes and Psorophora. In India, the various species of Anopheles, Culex, Aedes and Mansonia are important as carriers of diseases. Malaria, Filariasis, Japanese Encephalitis (JE), Dengue fever and Dengue Haemorrhagic Fever (DHF) are the major mosquito borne diseases in India (William 2000).

Culex spp. occur in all climatic zones ranging from forest to semi desert zones. Altitude does not seem to limit distribution, since they are observed at elevations of 2770 to $5500 \mathrm{~m}$ in India and also in mines at depths of 1,250m below the sea level (Bhat 1975; Renapurkar et al. 2001). At lower elevations, C. quinquefasciatus populations occur in high numbers with relatively little seasonal variation, although high numbers are found during the third quarter of the year. In contrast at middle $(\approx 600-1000 \mathrm{~m})$ and high elevations $(\approx 1300$ $1500 \mathrm{~m})$ mosquito densities are much lower with well pronounced seasonal variations (Lapointe 2000).

Urbanization is a continuous process in developing countries like India and this has naturally led to aggregation of population. Further, due to rapid industrialization, large numbers of labourers migrate from rural to urban areas in search of job opportunities. This has resulted in the development of many slums with no proper sanitary and waste water disposal arrangements. Due to unplanned town expansions, the peripheral areas of towns bordering villages have become semi-urbanized and this process continues unchecked. The results are environmental changes including the creation of water bodies highly conducive for the breeding of mosquitoes. The increasing breeding potential 
of these ubiquitous mosquitoes can thus be attributed to the development process (Rajagopalan \& Das 1988).

\section{MATERIALS AND METHODS}

Coimbatore is located at the foothills of the Western Ghats a mega biodiversity hotspot. It is the third largest city in Tamil Nadu located at $10^{\circ} 50^{\prime}-11^{\circ} 02^{\prime} \mathrm{N}$ \& $76^{\circ} 56^{\prime}$ $77^{\circ} 01^{\prime} \mathrm{E}$. The city has an average elevation of $442 \mathrm{~m}$ above the mean sea level. The total area of Coimbatore City is $1287 \mathrm{~km}^{2}$ with a population of $9,40,000$ (Census of India 2001).

The Sanganoor Canal originates in the Western Ghats, (Kuridimalai Hills) and flows from west to east entering Coimbatore at the Coimbatore-Mettupalayam Road and flows for about $10 \mathrm{~km}$ within the city. It is a major open drainage system which has intricate linkage with the storm water supply, domestic sewage and industrial effluent disposal.

Gandhipuram is a commercial neighbourhood located at the heart of the city, while Kavundampalayam and North Coimbatore are located on the Mettupalayam Road. These highly populated residential areas with open drainage were selected for the study.

Fortnightly collections of adult mosquitoes were made from November 1999 to October 2001 using mosquito sweep nets. Collected mosquitoes were anaesthetized using chloroform, examined under stereo binocular microscope (Carl Zeiss stemi dv4) and sorted. Identification is based on Christophers (1933) and Barraud (1934).

During the study period meteorological parameters such as temperature, relative humidity and rainfall were also recorded. Daily meteorological data were collected from the Meteorological Department, Tamil Nadu Agriculture University, Coimbatore.

\section{Statistical analysis}

Meteorological factors and mosquito population estimates were subjected to correlation and multiple regression analyses. Data were also subjected to Canonical Correspondence Analysis (CCA) to study the pattern of variation in the populations and summarize multivariate data in scatter diagram. Acanonical ordination technique was used to explain the patterns of variation in mosquito species with the environmental variables by combining regular ordination with aspects of regression (Jongman et al. 1987). In the present study population data for mosquito species was assessed along with environmental variables such as maximum and minimum temperature $\left({ }^{\circ} \mathrm{C}\right)$, relative humidity $(\%)$ at $0722 \mathrm{hr}$ and at $1422 \mathrm{hr}$, and rainfall $(\mathrm{mm})$. CCA was carried out using the software PAST (Palaeontological Statistics Software package for education and data analysis, a free ware).

\section{RESULTS}

\section{Population Studies}

During the study period 13 species were recorded in the three localities of North Coimbatore, Gandhipuram and Kavundampalayam. Of these four species Culex. quinquefasciatus, C. pseudovishnu, C. gelidus and Armigeres subalbatus were recorded throughout the period of two years while nine species $C$. vishnu, $C$. tritaeniorhynchus, $C$. bitaeniorhynchus, $A$. albopictus, $A$. vittatus, $A$. aegypti, $A$. vexans, $A$. subpictus and $A$. vagus were recorded less frequently and only during certain periods.

Culex quinquefasciatus was the predominant species in North Coimbatore and showed a trend of increase in February 2000 (34) with a peak in October 2001 (42). Maximum number of $C$. pseudovishnu were recorded in November 1999 and January 2000 (30). Population of A. subalbatus peaked in July 2001 (20). Compared to North Coimbatore the population of $C$. quinquefasciatus was less in Gandhipuram (Figs. 1-10). Population of $A$. subalbatus peaked in January 2000 (42) and moderate numbers were recorded during March 2000 (26), February 2000 (19), October 2000 and September 2001 (18).

Observations made in Kavundampalayamareashowed that maximum number of $C$. quinquefasciatus was in May 2000 (18) and the minimum in August 2000 (4), February and April 2001 (4). However, A. subalbatus registered high densities in March 2000 (47) and in February 2001 (39). A comparative analysis of the four species in the three localities of North Coimbatore, Gandhipuram and Kavundampalayam indicated that $C$. quinquefasciatus was the predominant species in North Coimbatore followed by $C$. pseudovishnu, whereas $A$. subalbatus was the predominant species in both Gandhipuram and Kavundampalayam areas.

\section{Statistical Analysis}

Correlation and regression analysis showed no relationship between mosquito populations and meteorological parameters when data were subjected to area-wise correlation analysis (Table 1). Population of $C$. quinquefasciatus from Gandhipuram were found to decrease with increasing maximum temperature $\left(31.89^{\circ} \mathrm{C}\right)$. C. pseudovishnu in Gandhipuram showed a similar trend, with a decrease in population density with an increase in maximum temperature. The relationship between the mosquito population of $A$. subalbatus from North Coimbatore and maximum temperature was more pronounced. Among the four species of mosquitoes, $C$. pseudovishnu in North Coimbatore and A. subalbatus in Gandhipuram showed an increase in population density with a decrease in minimum temperature $\left(21.75^{\circ} \mathrm{C}\right)$ and a significant negative correlation was observed between these two parameters. Study of mosquito population in relation to humidity $(0722 \mathrm{hr})$ indicated that numbers 


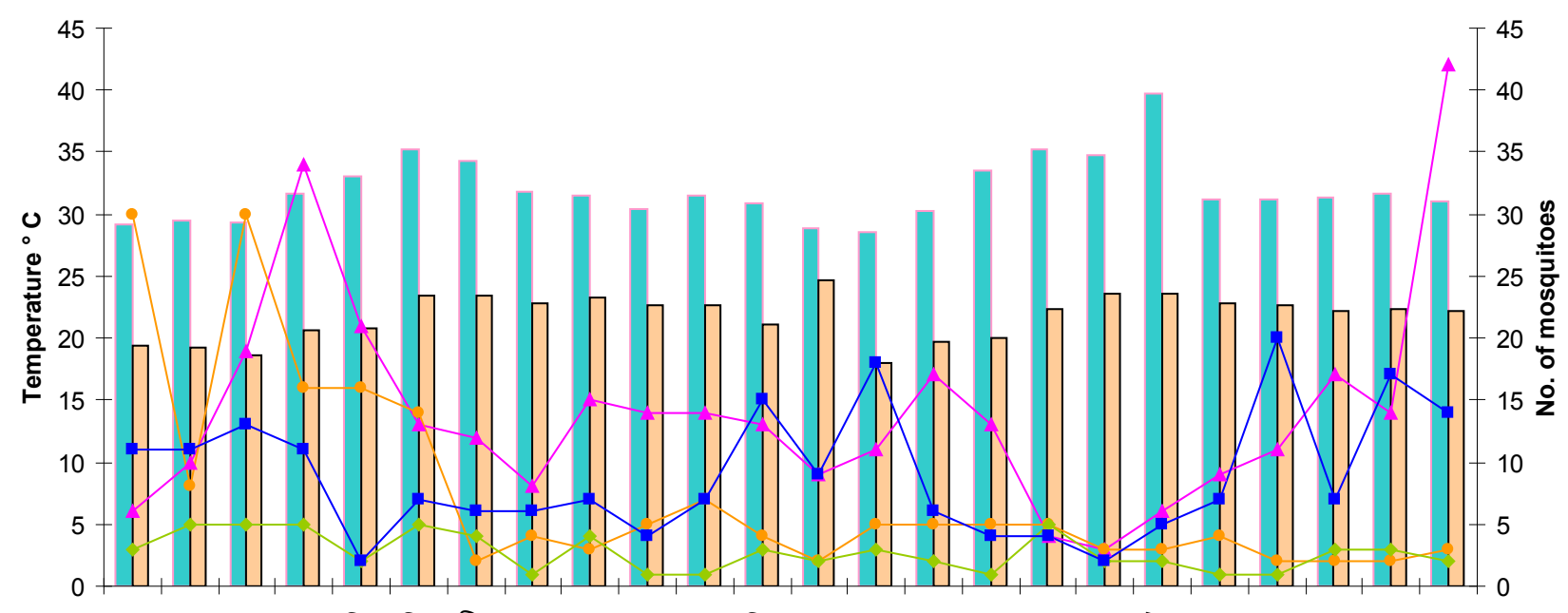

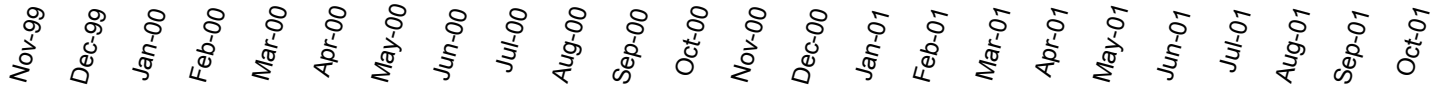

Month \& Year

Max temp ${ }^{\circ} \mathrm{C} \sqsubset \operatorname{Min}$ temp ${ }^{\circ} \mathrm{C} \longrightarrow$ C. quinquefasciatus $\because \mathrm{C}$. pseudovishnu $\longrightarrow \mathrm{C}$. gelidus $\rightarrow-\mathrm{A}$. subalbatus

Figure 1. Population dynamics of mosquito species in relation to temperature (maximum and minimum) in North Coimbatore

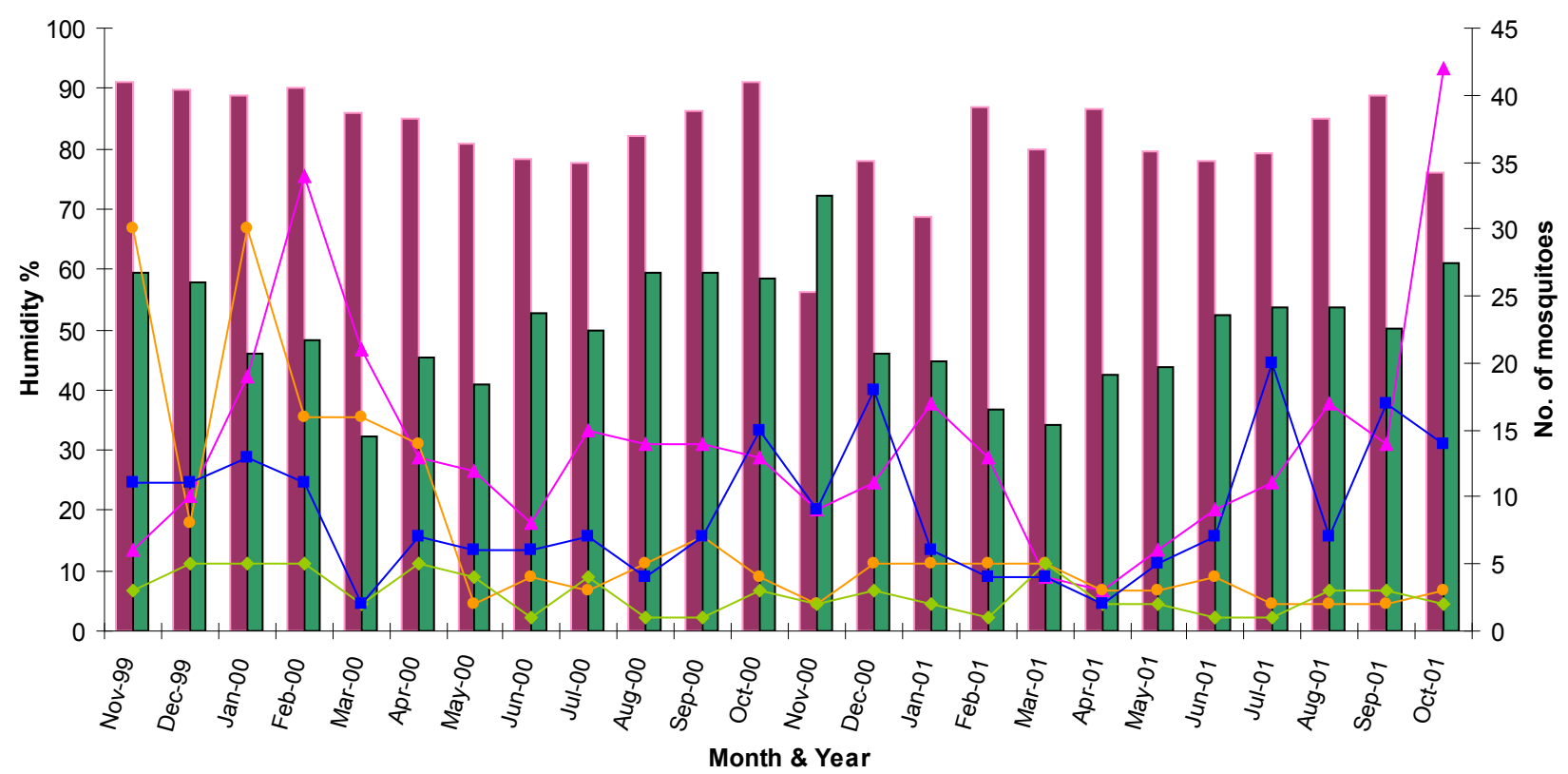

Humdity $(07.22 \mathrm{~h}) \square$ Humidity $(14.22 \mathrm{~h}) \multimap$ C. quinquefasciatus $\longrightarrow$ C. pseudovishnu $\longrightarrow$ C. gelidus $\rightarrow$ A. subalbatus

Figure 2. Population dynamics of mosquito species in relation to humidity (0722 \& 1422 hr) in North Coimbatore 


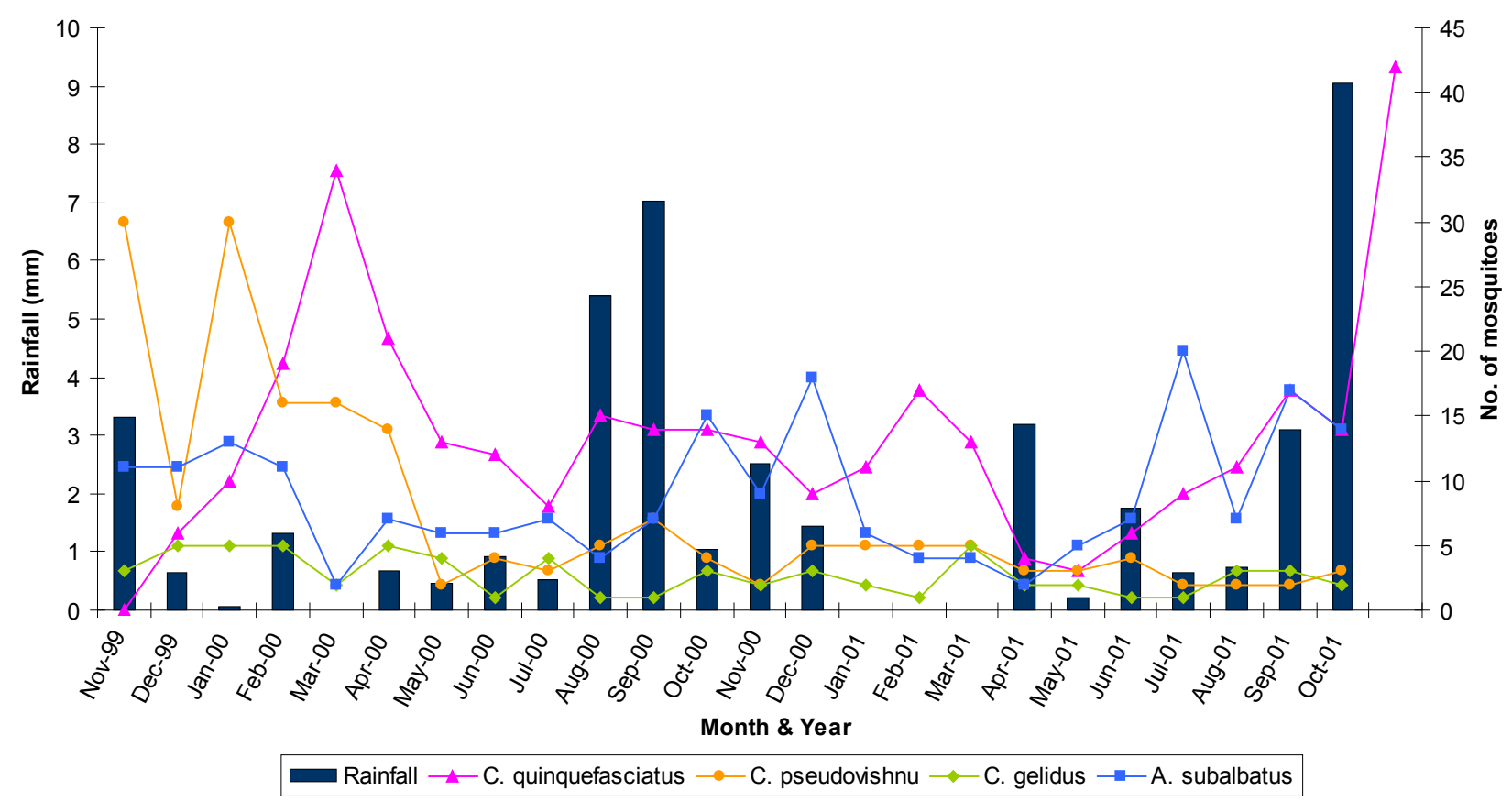

Figure 3. Population dynamics of mosquito species in relation to rainfall in North Coimbatore

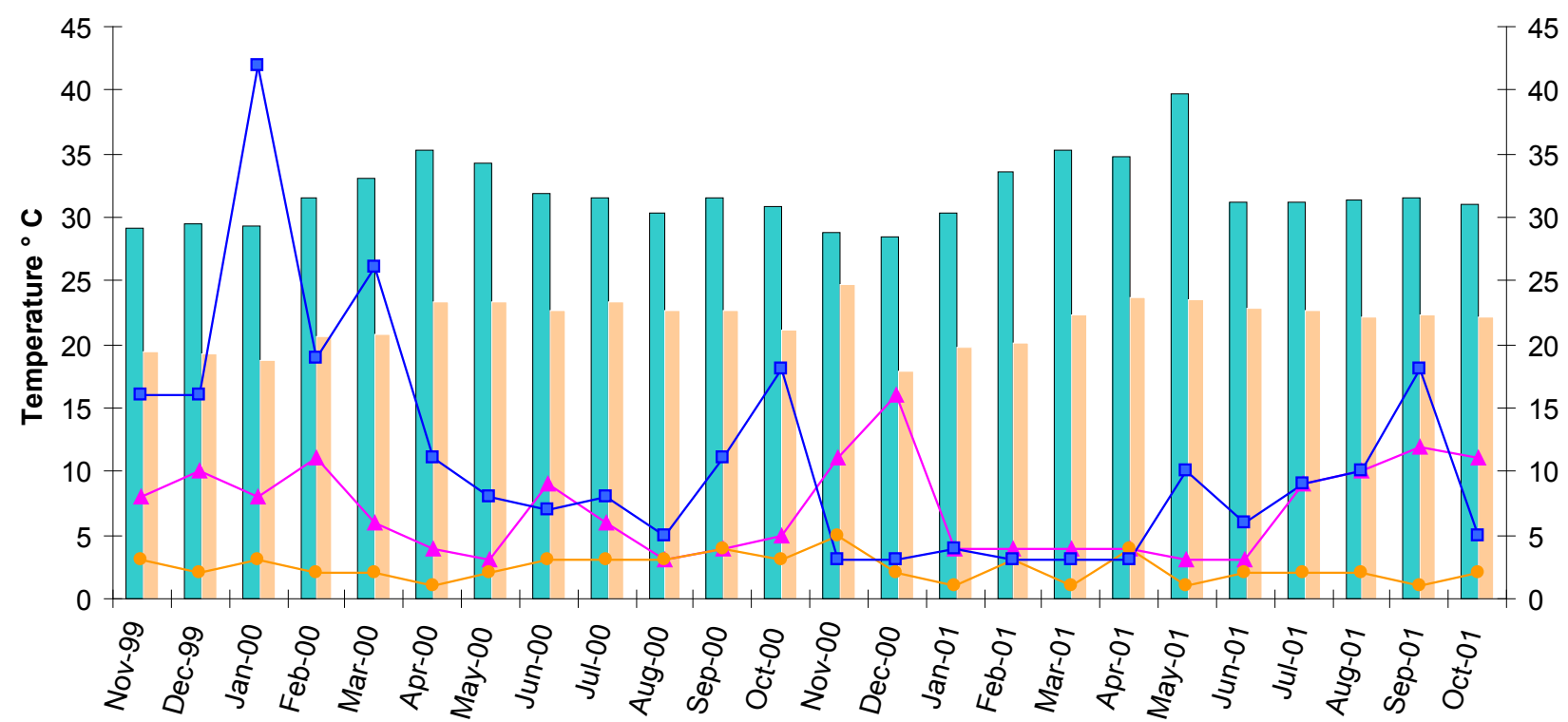

Month \& Year

$\square$ Max temp ${ }^{\circ} \mathrm{C} \backsim$ Min temp ${ }^{\circ} \mathrm{C} \multimap \mathrm{C}$. quinquefasciatus $\longrightarrow \mathrm{C}$. pseudovishnu $\longrightarrow$ A. subalbatus

Figure 4. Population dynamics of mosquito species in relation to temperature (maximum and minimum) in Gandhipuram 


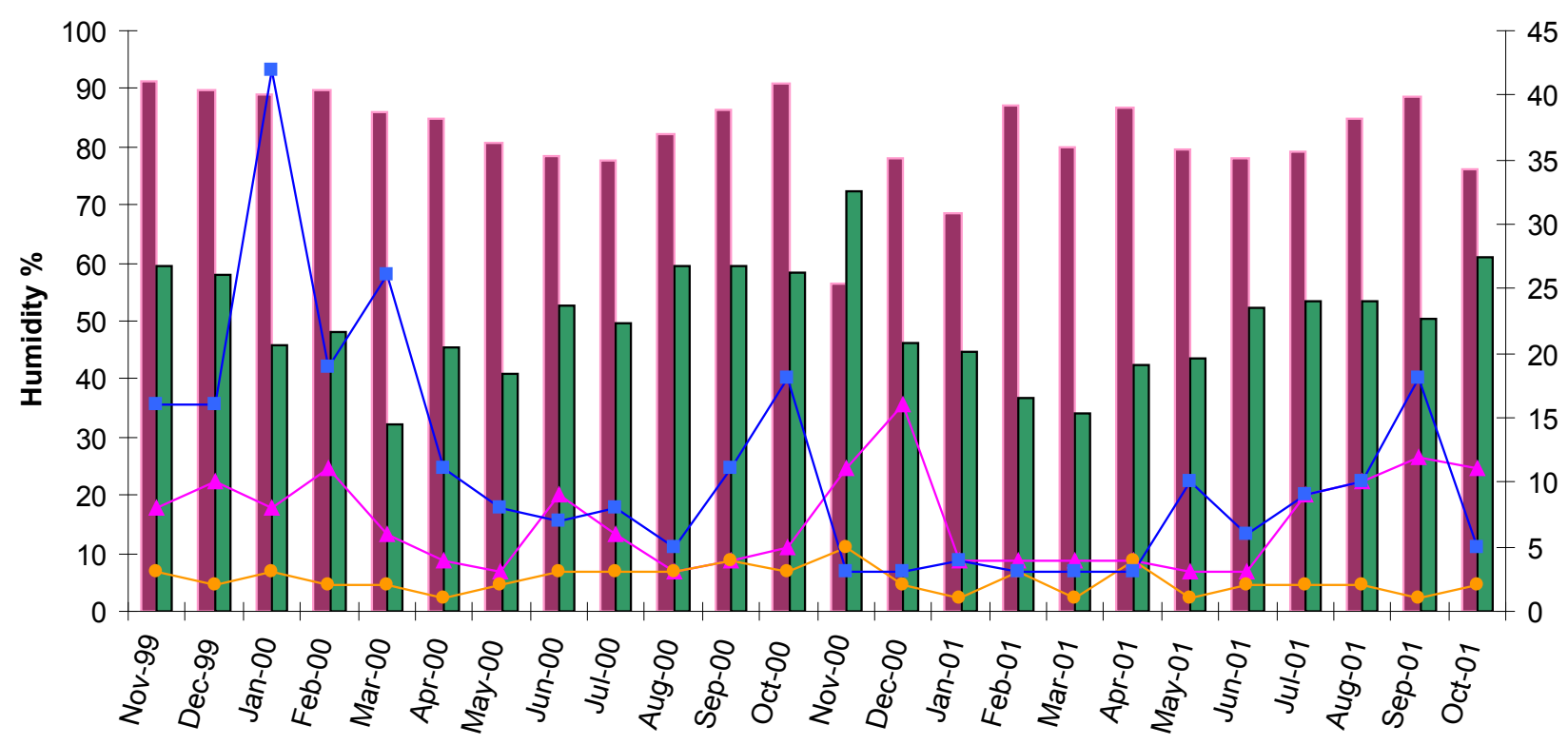

Month \& Year

- Humidity $(07.22 \mathrm{hrs}) \square$ Humidity $(14.22 \mathrm{hrs}) \rightarrow$ C. quinquefasciatus $\rightarrow$ C. pseudovishnu $\rightarrow-$ A. subalbatus

Figure 5. Population dynamics of mosquito species in relation to humidity (0722 \& $1422 \mathrm{hr}$ ) in Gandhipuram

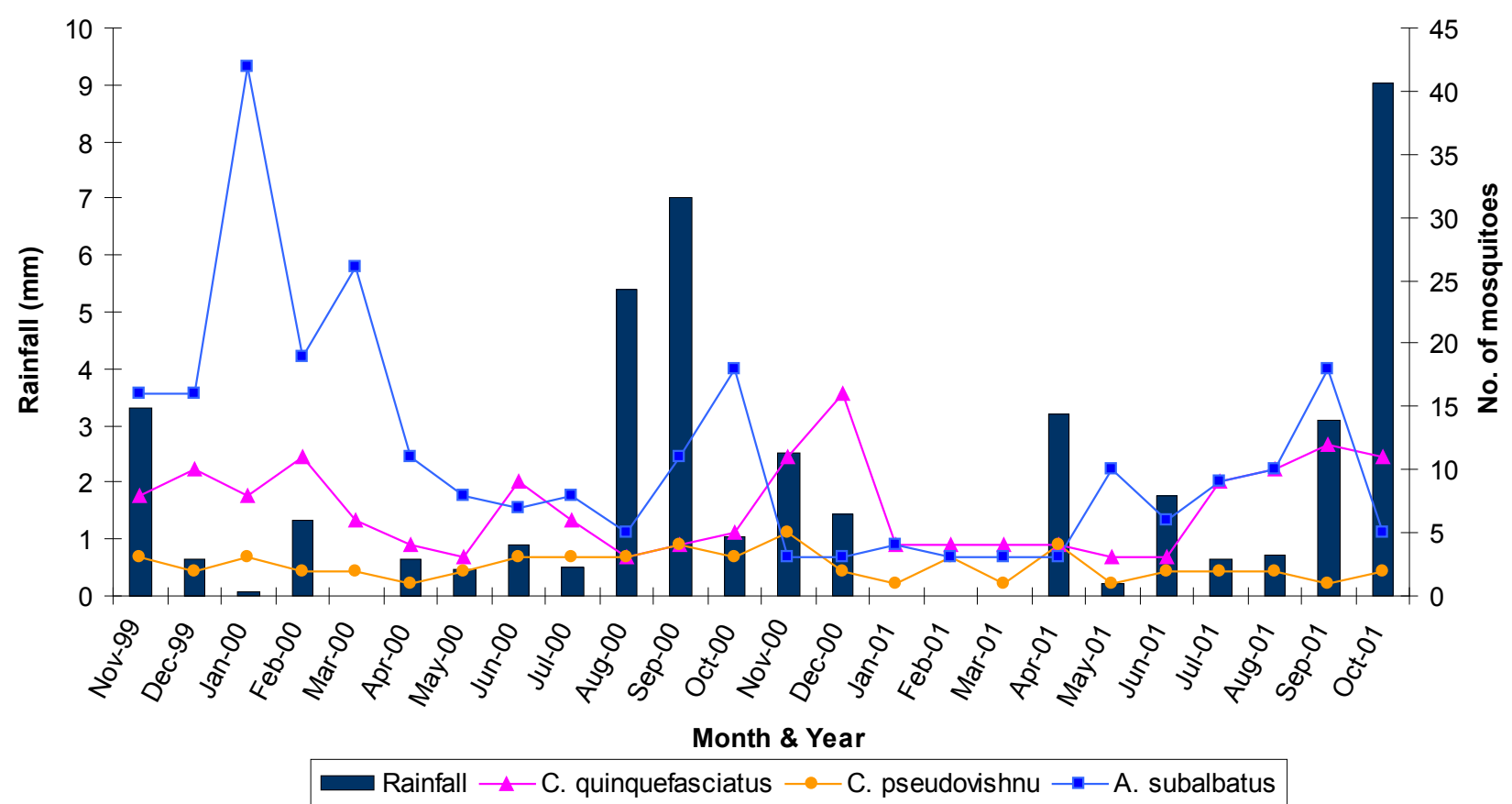

Figure 6. Population dynamics of mosquito species in relation to rainfall in Gandhipuram 


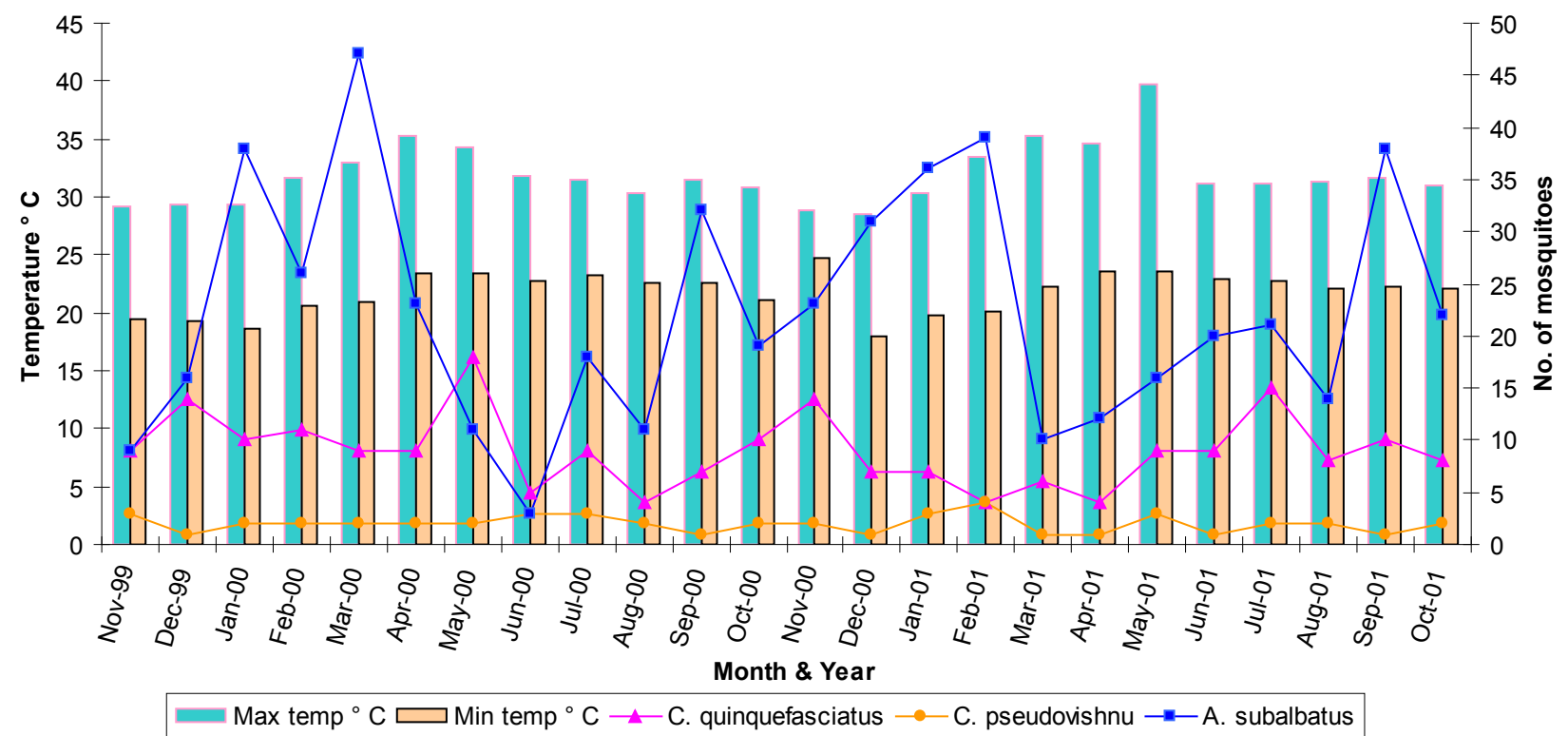

Figure 7. Population dynamics of mosquito species in relation to temperature (maximum and minimum ) in Kavundampalayam

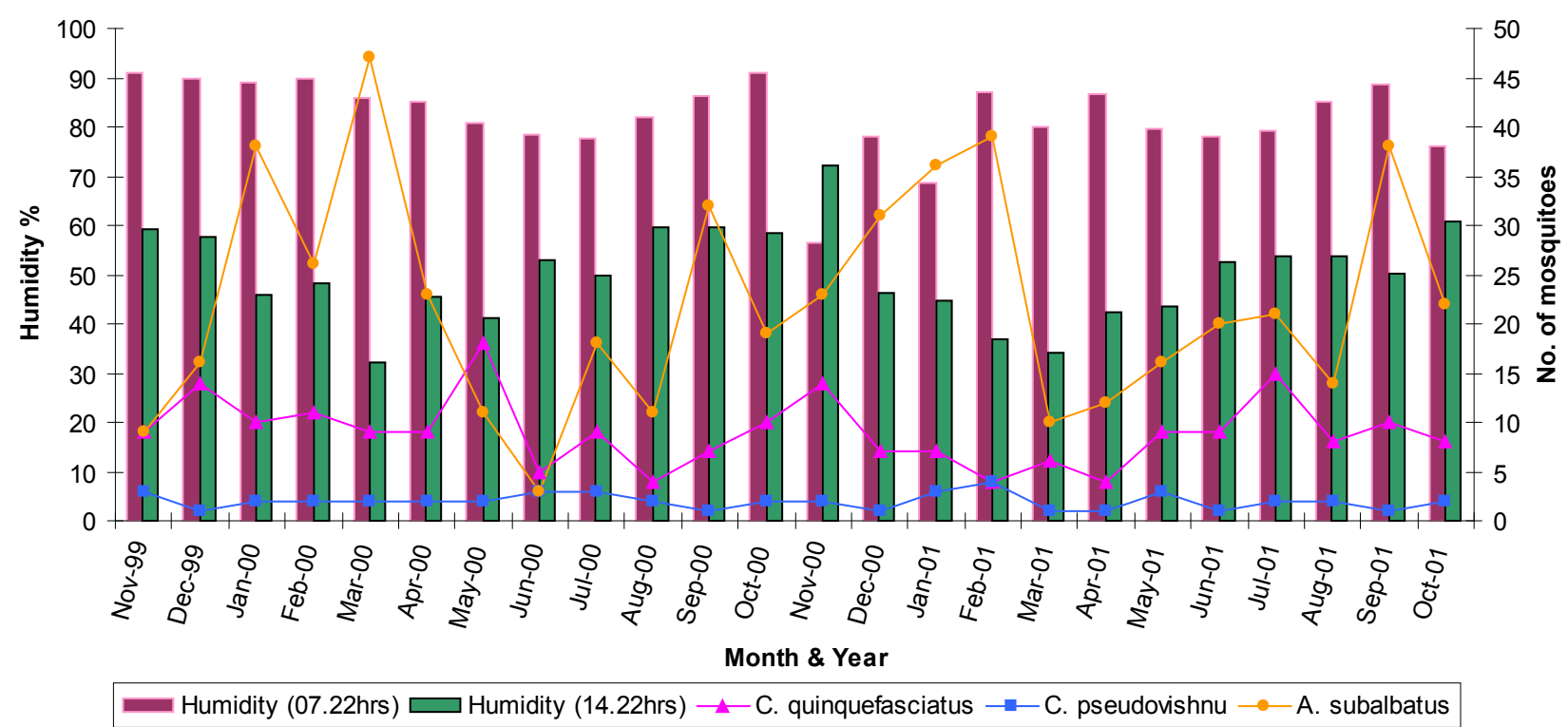

Figure 8. Population dynamics of mosquito species in relation to humidity (0722 \& $1422 \mathrm{hr}$ ) in Kavundampalayam 


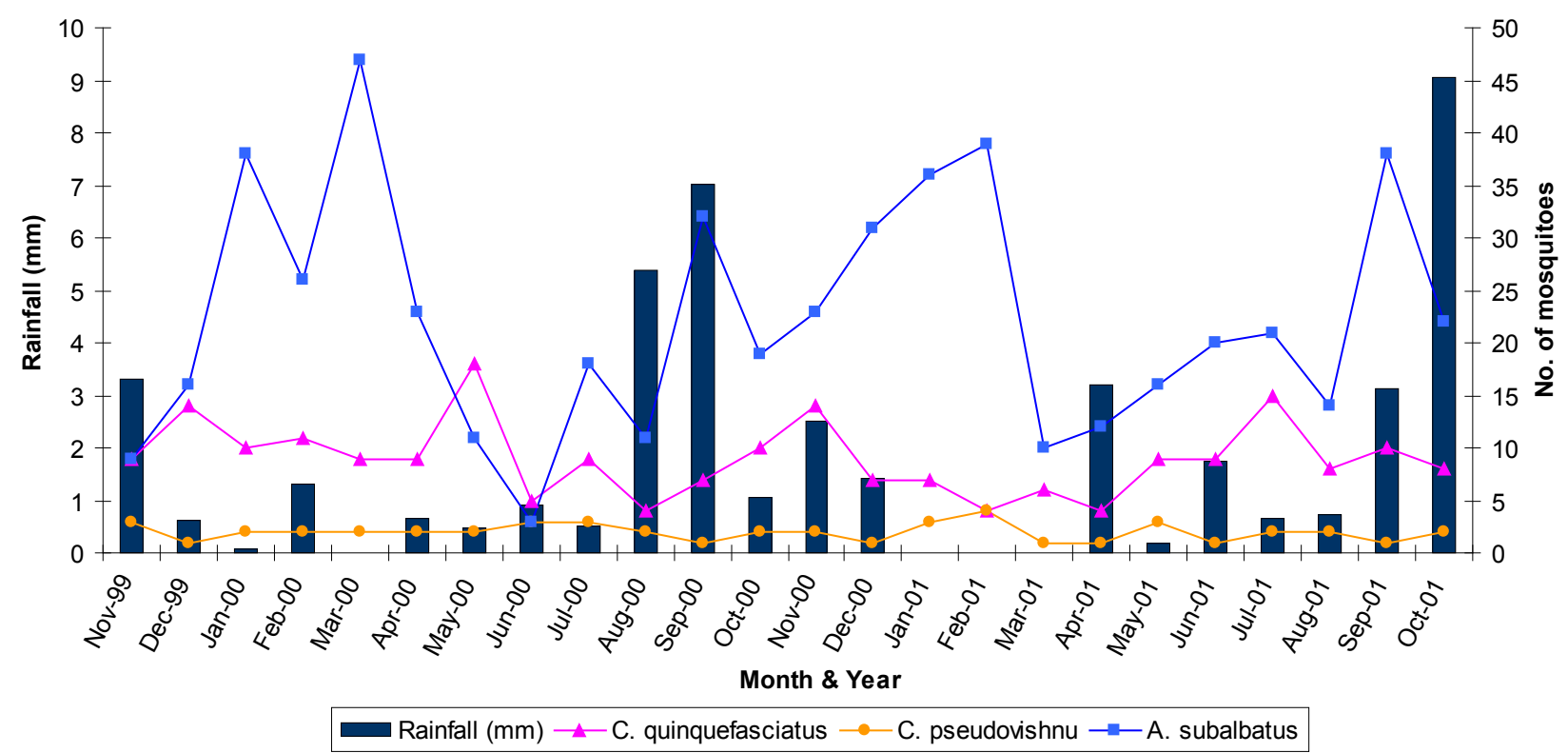

Figure 9. Population dynamics of mosquito species in relation to rainfall in Kavundampalayam

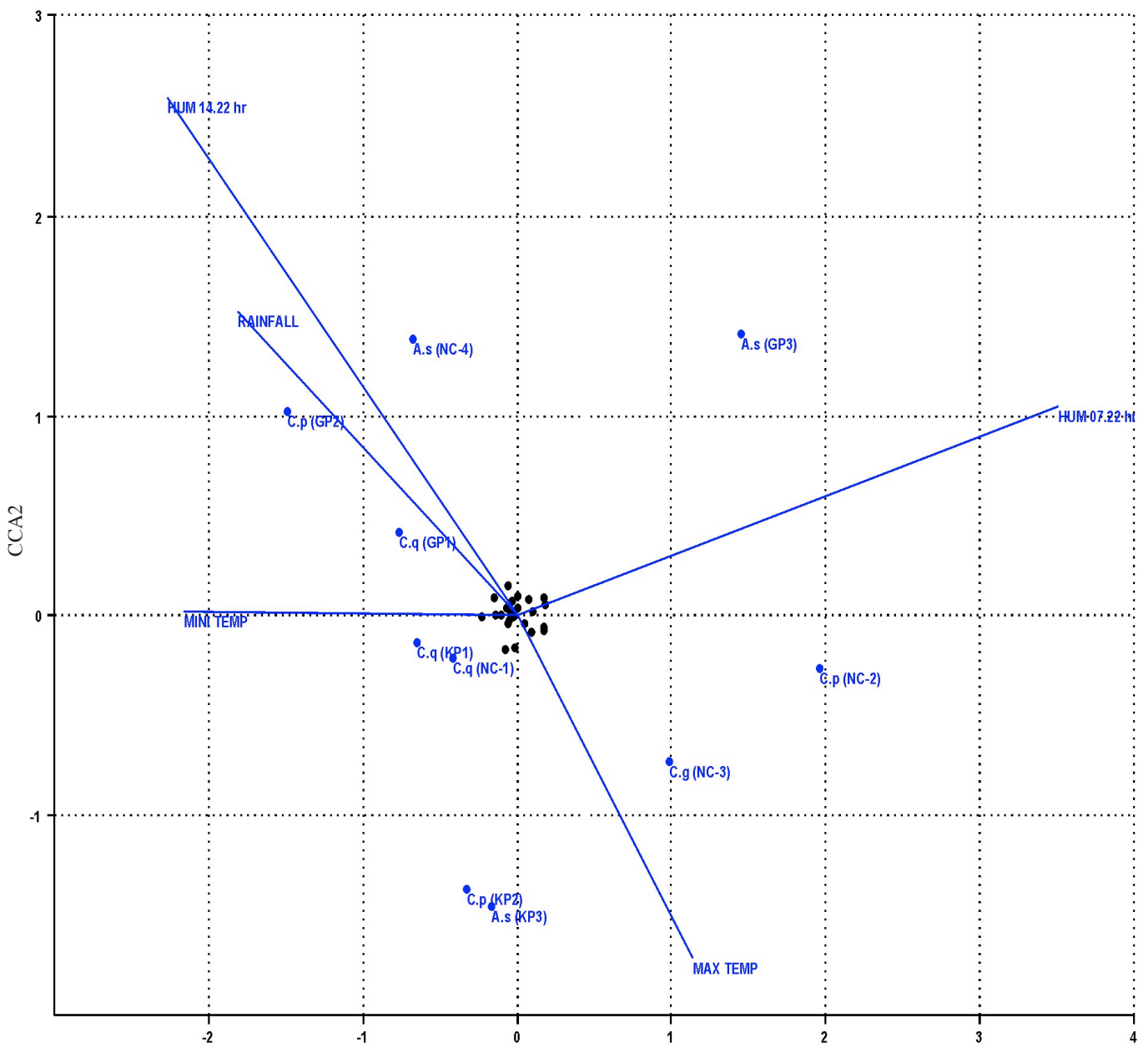

NC - North Coimbatore; GP - Gandhipuram; KP - Kavundampalayam

C.q. - Culex quinquefasciatus; C.p. - Culex pseudovishnu; C.g. - Culex gelidus; A.s. - Armigeres subalbatus

Figure 10. Cano plot showing the distribution of mosquito populations from three areas of Coimbatore from November 1999 - October 2001 
Table 1. Correlation between mosquito populations and meteorological parameters

\begin{tabular}{|l|l|l|c|c|c|}
\hline Mosquito Species & Area & Meteorological parameters & $\begin{array}{c}\text { Estimated } \\
\text { Parameter Humidity } \\
\%(1422 \mathrm{hr}) \mathbf{X}_{4}\end{array}$ & $\mathbf{F}$ & $\mathbf{R}^{2}$ \\
\hline C. quinquefasciatus & Gandhipuram & Max. Temperature $\left({ }^{\circ} \mathrm{C}\right)(33.05)$ & $-0.82^{*}$ & 10.75 & $0.33^{*}$ \\
\hline A. subalbatus & North Coimbatore & Max. Temperature $\left({ }^{\circ} \mathrm{C}\right)(41.46)$ & $-1.02^{*}$ & 7.97 & $0.27^{*}$ \\
\hline C. pseudovishnu & North Coimbatore & Min. Temperature $\left({ }^{\circ} \mathrm{C}\right)(60.64)$ & $-2.44^{*}$ & 9.25 & $0.30^{*}$ \\
\hline A. subalbatus & Gandhipuram & Min. Temperature $\left({ }^{\circ} \mathrm{C}\right)(57.51)$ & $-2.14^{*}$ & 4.79 & $0.18^{*}$ \\
\hline C. pseudovishnu & North Coimbatore & Humidity $(\%)(07.22(-30.39)$ & $0.46^{*}$ & 5.63 & $0.20^{*}$ \\
\hline A. subalbatus & Gandhipuram & Humidity $(\%)(07.22 \mathrm{~h})(-40.22)$ & $0.62^{*}$ & 9.14 & $0.29^{*}$ \\
\hline
\end{tabular}

* - Statistically significant at $5 \%$ level

of C. pseudovishnu from North Coimbatore showed a positive relationship with humidity. A similar positive correlation with humidity was recorded for $A$. subalbatus in Gandhipuram and C. pseudovishnu and A. subalbatus from Gandhipuram. Of the four species observed, $C$. quinquefasciatus numbers in North Coimbatore showed a positive correlation with rainfall. For the other areas, rainfall had no significant effect on mosquito populations. Numbers of $C$. gelidus were not found to be significantly associated with environmental variables.

\section{Canonical Correspondence Analysis}

Distribution of mosquito species in relation to environmental variables like maximum temperature $\left({ }^{\circ} \mathrm{C}\right)$ and minimum temperature $\left({ }^{\circ} \mathrm{C}\right)$, relative humidity $(\%)$ at $0700 \mathrm{hr}$ and $1400 \mathrm{hr}$ and rainfall $(\mathrm{mm})$ were analyzed by ordination based on canonical correspondence analysis for two years (November 1999 to October 2001) in the three study areas, North Coimbatore, Gandhipuram and Kavundampalayam (Fig. 10). A positive relationship with humidity $(0722 \mathrm{hr}$ ) was observed in Gandhipuram for $A$. subalbatus, and with maximum temperature for $C$. pseudovishnu and $C$. gelidus in North Coimbatore. Most of the clusters are clumped together in the base, showing the low importance of seasons (Fig. 1). A. subalbatus showed a positive relationship with humidity (1422hr) in North Coimbatore and also a positive relationship with humidity (0722hr) in Gandhipuram. In Gandhipuram C. pseudovishnu had a positive relationship with rainfall. C. quinquefasciatus in Kavundampalayam and North Coimbatore area showed more inclination towards minimum temperature. Most of the clusters are clumped together in the base exhibiting the less importance of seasons (Fig. 10).

\section{DISCUSSION}

During the study period, 13 species were recorded in the three test localities. Of these four species, $C$. quinquefasciatus, C. pseudovishnu, C. gelidus and $A$. subalbatus were recorded throughout the period of two years. However, nine species, viz., C. vishnu, $C$. tritaeniorhynchus, $C$. bitaeniorhynchus, $A$. albopictus, $A$. vittatus, $A$. aegypti, $A$. vexans, $A$. subpictus and $A$. vagus were recorded less frequently which agrees with the established fact of seasonal occurrence of mosquitoes (Bosgelmez et al. 1994, 1995).

In the present study $C$. quinquefasciatus was found to be the predominant species in North Coimbatore, whereas $A$. subalbatus was the predominant species in Gandhipuram and Kavundampalayam closely followed by $C$. quinquefasciatus. The high prevalence of $A$. subalbatus and Culex species in Gandhipuram and Kavundamapalayam may be attributed to the presence of open sewage canals and closeness to Sanganoor channel into which sewage is discharged at various points in its course. These polluted waters offer an ideal breeding ground for mosquitoes. Similar observations have been made by Amerasinghe (1982) who found $A$. subalbatus breeding commonly in polluted ground water collections as well as in container habitats like tree holes and bamboo stumps.

Studies on population dynamics of mosquito species have been undertaken by several investigators (Alten et al. 2000; Gleiser, et al. 2000; Ahumada et al. 2004; Simsek 2003, 2004). According to Alten et al. (1997), the highest number of mosquitoes was found during summer and autumn and less number during winter and early spring. Similar observations were made by Bosgelmez et al. (1995) who recorded highest numbers of species during early summer especially in June, with the total number of adults collected increasing from June to September and decreasing in October. Contrary to this observation in the present investigation highest numbers were recorded invariably in January to March and October to December which might be due to the prevailing monsoonal pattern.

Rao et al. (1981), Dash et al. (1998) and Dixit et al. 
(2002) observed a low density of $C$. quinquefasciatus in May and a high density in February in East Godavari District of Andhra Pradesh. Similar high density had been observed in North Coimbatore in the month of February in the present study. However, in the other two areas high density was recorded in November to December. Dhar et al. (1968) also recorded high densities in November to December.

Population studies on $A$. subalbatus are meagre. In the present study peak population was recorded invariably from January to March and population was comparatively low in May to August in both Gandhipuram and Kavundampalayam. C. pseudovishnu population was abundant in North Coimbatore area and highest density was recorded in November 1999 and January 2000. In Gandhipuram and Kavundampalayam low density was observed throughout the study period. According to Joshi \& Bansal (1991), C. pseudovishnu prefers outdoor habitats where both temperature and relative humidity are high. In the present study C. pseudovishnu numbers were higher when the temperature was optimum in a range of 29.21 to $29.41^{\circ} \mathrm{C}$ and humidity ranging from $89-91 \%$.

\section{REFERENCES}

Ahumada, J., D. Lapointe \& D.M. Samuel (2004). Modeling the population dynamics of Culex quinquefasciatus (Diptera: Culicidae), along an elevational gradient in Hawaii. Journal of Medical Entomology 41(6): 1157-1170.

Alten, B., R. Bellini, S.S. Caglar, F.M. Simsek \& S. Kaynas (2000). Species composition and seasonal dynamics of mosquitoes in the Belek region of Turkey. Journal of Vector Ecology 146-154pp.

Alten, B., S.S. Caglar, N. Ozer \& F.M. Simsek (1997). Integrated Mosquito Control in the Belek Region, Turkey. $2^{\text {nd }}$ Sove International Congress of Vector Ecology. Orlando. FL. October 22, 1997.

Amerasinghe, F.P. (1982). Observations on the mosquitoes (Diptera: Culicidae) of Udawattakele forest, Sri Lanka. Journal of National Science Council 10: 81-97.

Barraud, P.J. (1934). The Fauna of British India. Diptera Volume IV. Family Culicidae. Tribe Megarhinini and Culicini. Tailor and Francis, London

Bhatt, H.R. (1975). A survey of hematophagous arthropods in Western Himalaya, Sikkim and Hill districts of West Bengal: records of mosquitoes collected from Himalayan region and Uttar Pradesh with ecological notes. Indian Journal of Medical Research 63: 1583-1608.

Bosgelmez, A., L. Cakmakci, B. Alten, Z. Ayas, K. Isik, H. Sumbal, A. Kuytul, A.S. Kocal, S. Kaynas, M. Temimhari \& F.M. Simsek (1994). Sivrisineklere karsi entegre mucadele, T.C. Turizm Bakanligi Yatirimlar Genel Mudurlugu Alt Yapi Dairesi Baskanligi. Yayin No: 1994 - 1, H.U. Fen Fakultesi Matbaasi, ISBN, $975-7478-82-2$. 759s.

Bosgelmez, A., L. Cakmakci, B. Alten, S. Kaynas, K. Isik, H. Sumbul, F.M. Simsek, Z. Ayas, M. Temimhan, R.S. Gokturk, S. Savasci, N. Pasli, A. Kuytul \& A.S. Kocal (1995). Sivrisineklere Karsi entegre mucadele II. T.C. Turizm Bakanligi Yatirimlar Genl Mudurlugu Alt Yapi Dairesi Baskanligi. Yayin No: 1995 - 1, H.V. Fen Fakultesi Matbaasi, ISBN 975 - 7479 - $90-3.1995$, 541s.

Census of India (2001). Data from the 2001 Census including cities, villages and town.

Christophers, S.R. (1933). The fauna of British India. Diptera. Volume IV - Family Culicidae, Tribe Anophelini, Taylor and Francis, London.

Dash, A.P., N. Mahapatra, R.K. Hazra \& A.S. Acharya (1998). Transmission dynamics of filariasis in Khurda district of Orissa, India. South East Journal of Tropical Medicine and Public Health 29: 20-25.

Dhar, S.K., M. Das, B.N. Srivastava, P.K.M. Menon \& P.C. Basu (1968). Seasonal prevalence, resting habits, host preference and filarial infection of Culex quinquefasciatus in Rajahmundry town, Andhra Pradesh. Bulletin of the Indian Society for Malaria and other Communicable Diseases 5: 79-87.

Dixit, V., A.K. Gupta, Omkataria \& G.B.K.S. Prasad (2002). Population dynamics of Culex quinquefasciatus filarial vector in Raipur city of Chattisgarh State. Journal of Communicable Diseases 34(3): 193.

Gleiser, R.M., D.E. Gorla \& G. Schelotto (2000). Population dynamics of Aedes albofasciatus (Diptera: Culicidae) South of Mar Chiquita Lake, Central Argentina. Journal of Medical Entomoogy 37(1): 21-26.

Joshi, V. and Bansal, S.K. (1991). Occurrence of Culex vishnu group of mosquitoes in the rural areas of a desert district (Bikaner). Indian Journal of Medical Research 93: 259-261.

Jongman, R.H.G., T.C.J.F. Braak \& V.O.F.R. Tongeren (1987). Data analysis in Community and Landscape Ecology. Centre for Agricultural Publishing and Documentation (Pudoc), Wageningen, The Netherlands, 299pp.

Knight, K.L. \& A. Stone (1977). A Catalogue of The Mosquitoes of The World (Diptera: Culicidae) - II Edition. Thomas say foundation, Entomological Society of America.

Lapointe, D. (2000). Avian malaria in Hawaii: the distribution, ecology and vector potential of forest-dwelling mosquitoes. PhD Thesis, University of Hawaii, Honalulu, HI.

Rajagopalan, P.K. \& P.K. Das (1988). What ails mosquito control programmes in India? Bulletin of Science 4: 14.

Rao, C.K., R.K. Sundram, M. Venkatanaryana, S.J. Rao, A. Chandrasekharan \& C.K. Rao (1981). Epidemiological studies on bancroftian filariasis in East Godavari District (Andhra Pradesh): Entomological aspects. Journal of Communicable Diseases 14: 138-140.

Renapurkar, D.M., S. Daptardar, S.D. Renapurkar \& R.D. Renapurkar (2001). Vegetable oil as mosquito larvicides. Pestology 25(4): 41-44.

Simsek, F.M. (2003). Seasonal population dynamics and breeding habitat diversity of Culex pipiens Linnaeus, (Diptera: Culicidae) in Golbasi District, Ankara, Turkey Journal of Entomological Research Society 5(1): 51-62.

Simsek, F.M. (2004). Seasonal larval and adult population dynamics and breeding habitat diversity of Culex theileri Theobald, (Diptera: Culicidae) in the Golbasi District, Ankara, Turkey. Turkish Journal of Zoology 28: 337-344.

WHO (1996). Report of the WHO is formal consultation on the evaluation on the testing of insecticides CTD / WHOPES / IC / 96:1, 69pp.

William, J.S. (2000). Mosquitoes-mankinds' enemy, pp.1-9. In: Recent Trends in Combating Mosquitoes. Loyola College, Chennai. 